\title{
On the origin of spaces: morphometric foundations of urban form evolution
}

Article

Accepted Version

Dibble, J., Prelorendjos, A., Romice, O., Zanella, M., Strano, E., Pagel, M. and Porta, S. (2019) On the origin of spaces: morphometric foundations of urban form evolution. Environment and Planning B: Urban Analytics and City Science, 46 (4). pp. 707-730. ISSN 2399-8091 doi: https://doi.org/10.1177/2399808317725075 Available at https://centaur.reading.ac.uk/74914/

It is advisable to refer to the publisher's version if you intend to cite from the work. See Guidance on citing.

To link to this article DOI: http://dx.doi.org/10.1177/2399808317725075

Publisher: SAGE Publications

All outputs in CentAUR are protected by Intellectual Property Rights law, including copyright law. Copyright and IPR is retained by the creators or other copyright holders. Terms and conditions for use of this material are defined in the End User Agreement.

\section{www.reading.ac.uk/centaur}

\section{CentAUR}


Central Archive at the University of Reading

Reading's research outputs online 


\title{
MAIN DOCUMENT REVIEWED
}

\section{On the Origin of Spaces: Morphometric Foundations of Urban Form Evolution}

\begin{abstract}
The modern discipline of urban morphology gives us a ground for the comparative analysis of cities, which increasingly includes specific quantitative elements. In this paper, we make a further step forward towards the definition of a general method for the classification of urban form. We draw from morphometrics and taxonomy in life sciences to propose such method, which we name "urban morphometrics". We then test it on a unit of the urban landscape named "Sanctuary Area" $(S A)$, explored in forty-five cities whose origins span four historic time periods: HISTORIC (medieval), INDUSTRIAL (19th century), NEW TOWNS (post WWII, high-rise) and SPRAWL (post WWII, low-rise). We describe each $S A$ through 207 physical dimensions, and then use these to discover features that discriminate them among the four temporal groups. Nine dimensions emerge as sufficient to correctly classify $90 \%$ of the urban settings by their historic origins. These nine attributes largely identify an area's "visible identity" as reflected by three characteristics: 1) block perimeterness, or the way buildings define the street-edge; 2) building coverage, or the way buildings cover the land; and 3) regular plot coverage, or the extent to which blocks are made of plots that have main access from a street. Hierarchical cluster analysis utilising only the nine key variables nearly perfectly clusters each $S A$ according to its historic origin; moreover, the resulting dendrogram shows, just after WWII, the first "bifurcation" of urban history, with the emergence of the modern city as a new "species" of urban form. With "urban morphometrics" we hope to extend urban morphological research and contribute to understanding the way cities evolve.
\end{abstract}

Evolution; Urban Morphometrics; Urban Morphology 


\section{Introduction}

Cities are crucial to human beings, society and the environment in the current urbanization age, the "metropolitan century". The environmental, economic and social performance of cities will, in the next three-four decades, shape the future of the planet. And yet, a rigorous and reliable understanding of how cities change, i.e. a "science of cities and city planning", is today just in its infancy (Batty, 2008; Batty, 2013). In this paper we look at one specific aspect of cities, their physical form. Cities are a product of human culture. As such, they change in time responding to changing human needs and habits, and yet they evidently share common properties at various scales both in space and time. Such properties are the spatial relationships between physical features such as neighbourhoods, blocks, streets, squares, buildings, parks, or rivers. This dimension of the urban space affects crucial non-spatial dynamics such as identity, walkability, safety, prosperity, quality of life, wellness and ultimately the resilience of the urban system at large (U.N.HABITAT, 2013; Feliciotti et al., 2016). A quantitative, comprehensive and systematic method to define, measure and classify urban form at this scale is necessary to explore, for example, why certain communities become safer, or develop higher levels of satisfaction or lower levels of car use and obesity, or thriving retail clusters. However, despite its importance and practical urgency, a reliable science of urban form measurement and classification, or "urban morphometrics", does not exist, nor consequently a true science of urban form evolution.

How can this still be the case, more than 150 years since the publication of "On the origin of species" (Darwin, 1859)? The analogy of cities as living organisms has informed how we look at cities since Plato some twenty-four centuries ago (Williams, 2001) up to our days (Steadman, 2008; Marshall, 2008), spanning from more conceptual (Sert, 1942) to explicitly bio/anthropomorphic approaches as in the case of Le Corbusier (Hegewald, 2013). However, it so appears that urbanists have consistently continued to pursue the "good city form" (Lynch, 1984) in a way that echoes that of the healthy adulthood in the growth of living individuals; and by so doing, they have produced a developmental rather than truly evolutionary form of the analogy (Batty and Marshall, 2009; Romice et al., 2017). In the modern era, this has been historically functional to the establishment of town planning as a discipline in the first half of the past century: if a perfect adulthood existed for our cities, planners would be the ones who knew how it would look like and how to get there; in that sense they literally acted in the role of God (or Nature), a surprisingly simplistic approach to a phenomenon of almost unconceivable complexity.

By the early 1970s, following repetitive and painful failures on the ground, fundamental concerns regarding "the assumptions on which the planning doctrine is based" (Martin, 1972) were raised in the name of an authentically "organic" approach to city planning, one springing from a scientific rather than purely metaphysical analogy

with nature and complexity. Key-figures such as Jane Jacobs (Jacobs, 1992, c.1961) and - crucially - Christopher Alexander, set the stage for the understanding of cities as 
non-linear systems (Alexander, 1965), drawing from the new sciences of complexity (Weaver, 1948). They called for a radical shift towards a notion of urban change as a mostly self-organized and open-ended trajectory, inherently irreconcilable with central control, including that of rational-comprehensive planning. However, as influential as they have been, these voices have gone fundamentally unheard in mainstream urban planning and design up to our days, alongside those that in the same years, from different camps, called for "an ecological view of planning systems" (Holling and Goldberg, 1971). In the end, "the application of evolutionary concepts within urban planning theory has largely remained a curious mix of generalizations, metaphors and the vestigial remnants of Geddesian evolution - at least, until recently" (Marshall and Batty, 2009: 462). The first signs of such new science of cities have emerged only in the last two decades, largely from outside the boundaries of established urban scholarship.

The most notable contributions come from complexity theories (including complex networks) and/or biology. A classical example is the fractal description of urban form where the intrinsic non-Euclidean geometry of human settlements is highlighted (Batty and Longley, 1994). Inspired by scaling theories in biology, recent studies demonstrate that some urban form metrics, such as the amount of transportation infrastructure, scale uniformly among world-cities (Bettencourt et al., 2007; Bettencourt et al., 2013); moreover, indices of economic performance such as Gross Domestic Product are found to scale in linear or super-linear manners with urban population. Such scaling offers both an explanation of the advantages of large cities' "agglomeration economy", as investigated by recent advancements in economic geography (Coe et al., 2007), and of the self-organized nature of urban economy at regional scale (Strano and Sood, 2016). A noteworthy flurry of literature also comes from the physics of complex networks (Boccaletti et al., 2006; Barthelemy, 2011): for example the urban road network has been found to fundamentally characterize patterns of urbanization (Cardillo et al., 2006) and types of cities (Strano et al., 2013), where road centrality seems to drive the evolution of large-scale urban territories (Strano et al., 2012). Networks have also been utilized to explore the relationships between road structure and the micro economy of cities, demonstrating that space centrality is key in the evolution of urban places (Hillier, 1996; Porta et al., 2010).

The role of established urban disciplines in such pioneering endeavour is nevertheless minimal; contributions from urban scholars are often part of fully interdisciplinary efforts the core of which sits well away from urban disciplines. This might explain why such interdisciplinary studies on cities struggle to generate a recognizable impact on urban planning and design: for example, they privilege a largescale approach where the analysis unit is the whole city, leaving the micro/meso scale of neighbourhoods and districts substantially unexplored. To find an authentic focus on evolution at the neighbourhood scale, we shall turn to a niche that emerged in the early 1960s from the parallel and indeed unrelated efforts of Italian architects and British geographers: urban morphology. Since the foundation of this discipline (Muratori, 1960; Conzen, 1960), urban morphologists looked at component elements of the "urban tissue" (Larkham and Jones, 1991) at the neighbourhood scale, with a specific focus on time. In any case, as much as to biological evolution and system ecology, planners remained largely impermeable to urban morphology too: its explicit focus on self-organization and 
evolution made it difficult for them to accept, unless distorted into a purely architectural abstraction (Marzot, 2002). However, several key-notions of urban morphology itself appear to some degree still elusive (Whitehand et al., 2014), resulting in a weak analytical ground: various components of urban form have been discussed in various ways, but there is little evidence that such components are generally meaningful, nor that their definitions are univocal or universally applicable or valid (Dibble et al., 2016). While this does not prevent comparative studies from successfully exploring specific cases even of significant extension, the construction of a general taxonomy of urban form needs to be pursued within a systematic, comprehensive and quantitative new framework.

In this paper we introduce and test such framework by classifying the form of forty-five urban areas. As biological evolution stemmed from the rigorous measurement of the form of living organisms and, on that basis, of their similarity, i.e. by biological morphometrics, we propose a study in urban morphometrics. To do so we: a) identify the unit of analysis, at the appropriate scale; b) define the constituent elements of urban form which are universally correspondent across all cases; c) measure the visible ("phenotypic") manifestation of these elements in a way which is rigorous and replicable; d) identify the smallest set of variables still capable to adequately cluster cases by similarity, where similarity is expressed only numerically and adequacy is measured against a clear validation theory; e) derive a picture of such clustering that highlights what can arguably be defined as the first "bifurcation" in urban history.

\section{Methods: Urban Morphometrics}

"Classification is the basic method which man employs to come to grips with and organise the external world. Plants and animals are in fact classified in basically the same way as non-living objects, on the basis of possession of various characters or relations which they have in common" (Heywood, 1976: 1).

The necessity to classify and organise the external world is the foundation of systematics, i.e. the "scientific study of the kinds and diversity of organisms and of any and all relationships among them" (Simpson, 1961: 7). The results are systems of classification based on the similarity between organisms; such systems can be used for the storage, retrieval and communication of information, facilitating predictions and generalisations of unknown organisms, or inferring relationships between the units that are classified, also known as "taxa" (Jeffrey and Heywood, 1977). According to Roth and Mercer morphometrics in biology is "the quantitative characterization, analysis, and comparison of biological form, [...] a means of extracting information about biological material and biological processes" (Roth and Mercer, 2000). The contribution of morphometrics is "precision in the ability (a) to recognize forms that are intermediate, (b) to judge degrees of proximity or similarity to other forms, and (c) to extrapolate or predict hypothetical, experimental, or non-existent extremes" (Roth and Mercer, 2000). The modus operandi of morphometrics is therefore "to quantify the size and shape of organisms with the methods of multivariate statistics" (Klingenberg, 2002: 4). This sheds light on the 
evolution of forms and in particular on transformations that happen between forms (D'Arcy Thompson, 1942, c.1917). Importantly, the rigorous description and classification of organisms according to their similarity is fundamentally distinct from inferring the ancestral relationships between them, which is specific of phylogeny (Borgmeier, 1957: 54). Nevertheless morphometric variables collected at the population level are still today relevant at various stages of character-based phylogenetic reconstruction (Roth and Mercer, 2000). According to MacLeod (MacLeod, 2002: 100), gaps in similarity "may arise as a result of a number of evolutionary processes, but their discovery, description, and interpretation represents the first and most basic task of all systematics research".

A major shift in biological morphometrics, or indeed a "revolution" (Rohlf and Marcus, 1993), occurred in the 1980s: "traditional" methods, based on the algebraic measurement of distances characterizing organs or entire organisms are now complemented by geometric methods based on graphic processes of shape recognition and manipulation through the identification of special "landmarks" (Reyment, 2010; Adams et al., 2013). This approach can be considered as a synthesis of two primary traditions of morphometrics: multivariate biometrics, focusing on statistical analysis of form, and geometric visualization, focusing on visible geometric shapes of organisms (Bookstein, 1993). In this respect, our approach to urban morphometrics starts off in a traditional way: we characterize urban form utilizing a vector of measures that quantify individual aspects of its constituent elements and their relationships in space.

In numerical taxonomy, Sneath and Sokal (1973) proceed by first identifying the Operational Taxonomic Unit $(O T U)$. OTU identification may entail taking into account multiple factors, such as classification purpose, structural organization of what is to be classified, its most appropriate rank and stage of development, or other not necessarily morphological factors. Crucially, in biological morphometrics the $O T U$ is normally associated with the individual living organism, which is in most cases unambiguous. In our case, the $O T U$ is instrumental in determining the features that we observe to assess similarities between different types of urban form. Such taxonomic characters are " $a$ characteristic (or feature) of one kind of organism that will distinguish it from another kind" (Sneath and Sokal, 1973); it is the character's phenotypic expression, or state, that we assess in our attempt to establish similarities and differences between OTUs. When comparing two different $O T U s$, we actually compare the various states of their characters. Therefore we must do so "over a set of characteristics applicable to both of them" (Sneath and Sokal, 1973), or homologous characters. For example, we may want to establish which are the species represented in a collection of plants; for that purpose we would classify individual plants rather than, for example, populations of plants. A choice regarding the scale of our observation leads to the identification of the $O T U$, the individual plant. Observation may reveal that some plants have serrated leaf edges while others have regular ones: "serrated" or "regular" are states of the leaf edge, which is regarded to be a homologous character of the leaf element of the observed organisms (the individual plants).

In the transition from life sciences to cities, the identification of the most appropriate $O T U$ becomes far less intuitive: what is the "individual organism" in cities? 
Is it the city itself, the district, the neighbourhood, the street? For our morphometrics to support both a general classification of urban forms and a reliable validation process, a suitable OTU must be: 1) unambiguous; 2) universally present in all cities; 3 ) large enough to represent a complete spectrum of all the constituent elements of urban form such that all their homologous characters can be rigorously defined and measured; 4) small enough to be morphologically specific (this excludes, for example, whole cities which exhibit enormous internal diversity); 5) functionally recognizable as units in the organizational structure of the city. In previous research, the "Sanctuary Area" (SA) was identified as a recognizable part of the urban tissue (Mehaffy et al., 2010) and simply defined as the portion of the urban tissue enclosed by main streets (fig. 1). SAs' size makes them both specific and comprehensive; at the same time, their boundaries (constituted by main streets) can be determined objectively (Porta et al., 2014). Moreover, as cities emerge and evolve by the emergence and evolution of their street network, $S A s$ can be considered by definition universal components of all cities across time and space. Therefore, we adopt the $S A$ as our $O T U$ : in this research, forty-five $S A s$ are studied, forty of which are in the United Kingdom. All the case studies are named after the city to which they belong, but they only represent one $S A$ within that city.

Figure 1. A notional Sanctuary Area.

The homologous characters of urban form must then be identified; these characters are features of basic elements of the $S A s$, in the same way that the leaf edge in a plant is a feature of one basic element of the plant, the leaf. To serve our purpose in this research, characters have to be: 1) significant features of the form and evolution of the urban fabric, as acknowledged in relevant literature; 2) universally present in all $S A s ; 3$ ) measurable remotely, without direct inspection in situ. The rigor of a morphometrics approach required a significant work to redefine univocally, as much as possible, components and elements of the taxonomic structure that were extensively present in literature — such as street, block, plot, building density, built front, street edge etc. —and nevertheless either informally or inconsistently defined, if at all: for example, at the element level we distinguish between Regular Plot and Internal Plot whereby, contrary to the latter, the former has a primary edge on, and access from, a public street (tab.1).

\section{Table 1. Taxonomic structure: definitions.}

In the end, we identified nine basic elements of urban form (tab. 2), i.e.: Urban Main (street), Local Main (street), Local (street), Building, Regular Plot, Internal Plot, Internal Way, Open Space and Natural Area. Such nine elements are constituent parts of three higher order components: the Street; the Block and the Natural Area. The overall structure they create is spatially hierarchical, in that the lower order elements are spatially entirely contained in, and exactly constitutional of, the higher order components; for example Blocks are exactly comprised of Regular Plots, Internal Plots, Open Spaces and Internal Ways. 
Table 2. Taxonomic structure for the morphometric analysis of Sanctuary Areas.

Seventy-five homologous characters were then identified for the description of the nine elements and the interactions between them. In several cases, one character is ultimately described by more than one variable in an attempt to fully capture its expression; in such cases, we typically calculate a set of five descriptors (variables) of the character's statistical distribution: Interquartile Average, Interquartile Range, Overall Minimum, Overall Maximum, Interquartile Standard Deviation. The complete set of the 207 variables finally utilized is offered in supplementary material (S1); variables span from, for example, the Built Front Ratio of blocks to the Covered Area Ratio of plots, or the Ingress/Egress Ratio of $S A s$.

How can we assess to what extent our choices regarding the scale of the $O T U$, the taxonomic structure and the set of variables, elements and characters, are effectively meaningful? It is important that a validation theory is clearly set out, which makes sense of the distinction between elements of urban form as it would do of the distinction between a wing and a beak in biological morphometrics. In our study, we propose that the validation of our system refers back to the historic origins of the case studies. It is established knowledge in urban morphology that the distinctive character, or the identity, of an urban fabric, results from the historic period of their formation. Scholars in urban morphology have extensively referred to this phenomenon with the notion of "morphological period" (Conzen, 1960; Whitehand, 1987); in short, the historic origin of an urban area has a direct and enduring impact on its evolution over time. What distinguishes urban fabrics of different historic origins in all evidence goes beyond factors of architectural language or style, and appears to be inherent to their long-lasting morphological structure. For example, there is evidence that the street layout is among the most resilient components of urban form, as well as the block and plot structure, which is directly linked with it (Moudon, 1986). The street layout then influences other crucial elements such as street centrality, building types, density and land uses (Caniggia and Maffei, 2001, c.1979). Because it is such morphological structure that we ultimately want to reveal, we need a model by which the resulting numerical expression of their form is conducive to correctly classifying typical cases in terms of their morphological period (i.e. historic origin).

To commence simply, we identify four highly distinguishable historic origin groups as described in literature: a) HISTORIC (compact medieval town centres); b) INDUSTRIAL (compact dense working class housing from the late 19th and early 20th century); c) NEW TOWNS (post-war modernist "towers-in-the-park" developments); d) SPRAWL (post-war low density and low rise "lollipop" suburbs). The four historic origin groups also belong to the higher taxonomic level of pre and post-WWII (pre-WWII including HistOrIC and INDUSTRIAL; post-WWII including NEW TOWNS and SPRAWL). The selection of the $S A s$ is informed by extensive literature review: cases, which are all contemporary "living" urban areas, are only included if they: 1) are widely acknowledged in the literature to be typical of their historic origin; and 2) are reasonably homogeneous, internally, in the expression of that typical form (fig. 2). Ultimately, the proposed urban 
morphometrics method will be good to the extent that it clusters cases according to their historic origins after only the numerical expression of their form is considered.

Figure 2. Examples of four SAs examined in this paper: (a) Caernarfon, HISTORIC; (b) Manchester, Industrial; (c) Harlow, New Town; (d) Milltimber, Sprawl. Geographic reference is in Table 3. Source: Google Map.

The proposed method is designed to support further developments in areas such as remote sensing and big data as pertinent to urban morphology (Carneiro et al., 2010). The actual measurement of $S A s$ is conducted manually after each of them was mapped in a Geographic Information System (GIS) environment: all 2D characters such as Building coverage are identified spatially on the map, while 3D characters such as Building Height are added after inspection through Google Street View, or similar publicly available online repositories; the database relative to the $S A$ was finally stored in a Microsoft Excel format. The overall database represents forty-five case studies, forty of which are from the UK, four are European non-UK, and one (Tripoli) is an Arabic historic centre from Libya, North Africa. The complete set of all the forty-five $S A s$ is reported in tab. 3 . Though for reasons of simplicity, with reference in particular to the homogeneity of the data sources, most $S A s$ have been selected within the UK, geographic colocation is not part of the selection criteria (while the historic origin is): on one hand this reflects the comprehensive scope of the method, which must be potentially applicable globally; on the other hand, it is a result of the nature of the research model, according to which the geographical clustering of specific taxa (types of urban form) should emerge - if at allfrom the sole consideration of their physical character, rather than inform upfront the definition of the types themselves.

Several multivariate statistical analyses, detailed in supplementary material (SR), were undertaken to address all phases of data processing, including method validation (Principal Component Analysis), variable ranking (Cost-Benefit Analysis) and taxonomic assessment (Hierarchical Clustering Analysis).

Table 3. Cases studies according to their historic origins: cases are Sanctuary Areas nominated after the city they belong to.

It is important to reiterate that this study is aimed at establishing and validating a method. Therefore it starts off by observing a purposefully simplified, and consequently partial, section of reality, reduced to only four highly distinguishable samples (historic origins groups) of the many more that may characterise the form of $S A s$ globally. It is also important to highlight that we do not compare cities, we compare $S A s$. Therefore, though we name every $S A$ after the city it belongs to, by no means the name implies any degree of representativeness of that $S A$ towards "its" city: in fact, a $S A$ in Birmingham may well be more similar to one in Manchester than to its neighbouring $S A$ in Birmingham, as 
much as a cyclamen in Birmingham is more similar to another cyclamen in Manchester than to its neighbouring camellias in Birmingham. In the context of the long-lasting organic analogy of cities, this position ultimately introduces a radical reconsideration of physical cities as the analogous of eco-systems rather than unitary living organisms, a position the profound implications of which are extensively discussed in chapter 4 .

\section{Validation and Results}

\subsection{Testing the Method and Identifying Core Variables}

To assess our method's reliability in classifying cases according to the numerical expression of their form, we first undertake a Principal Component Analysis ( $P C A$ ) (Hair et al., 2006; Brereton, 2009). PCA allows a phenomenon originally described by multiple variables to be described by a reduced set of axis, maintaining an acceptable level of representativeness; for details see supplementary material (SR). We observe (fig. 3, panel a) that pre and post-WWII cases are linearly partitioned into two unequivocal groups by $P C 1$; on $P C 2$, cases can again be partitioned linearly with higher precision differentiating between the pre-WWII (Historic and Industrial) origin groups. Further (fig. 3, panel b), information is also held in $P C 3$, specifically regarding post-WWII origin groups (New Towns and Sprawl): this is confirmed in 2D scores plot of $P C 1$ and $P C 3$ reported in supplementary material (S2). The first three PCs reveal that there is an inherent separation in cases consistent with their known historic origins: $P C 1$ distinguishes pre from post-WWII cases; $P C 1$ and $P C 2$ distinguish pre from post-WWII cases as well as the two pre-WWII origin groups. With the first three $P C s$ there is nearly perfect linear distinction between the four origin groups.

We present the cumulative variance of the $P C s$ in supplementary material (S3). The loadings of variables onto each of the $P C s$ reveals which are the metrics that are most correlated with the differentiation between cities based on their historic origins. The 207 metrics are classified based on their relevance to the Sanctuary Area, Street Network, Blocks, Regular Plots, Internal Plots and Street Frontages and are sub-classified in numerous categories. In supplementary material (S4) we demonstrate the relevance of the first 25 highest-loading metrics for each of the first three PCs. The distinction between pre and post-WWII cases can be predominantly attributed to the structure and composition of the Blocks; the distinction between Historic and Industrial cases attributed to the structure, arrangement and composition of the Regular Plots; the distinction between New Towns and Sprawl cases attributed to the expression, connectivity and geometry of the Street Network.

In summary, cases attributed by literature to the same historic origin group, are most consistently clustered together, which validates the analytical method proposed. 
Figure 3. Principal Component Analysis (PCA) of the forty-five $S A s$ (207 variables): (a) Along PC1 and PC2; (b) Along PC1, PC2 and PC3.

Further, we explore the least subset of the 207 variables that still accurately clusters cases in the four historic origin groups, i.e. the most discriminatory variables. We design a Cost-Benefit Analysis ( $C B A$ ) to test the relative value of incrementally considering higher-ranked variables in the model (Brereton, 2009). The analysis proceeds iteratively: in each iteration: 1) we divide the 45 cases into a test set and a training set: 28 cases (seven for each of the four historic origin groups) are randomly selected into the training test, the remaining 17 falling into the test set; 2) we apply the Fisher Weight discriminatory test, described in supplementary materials (SR), to rank the variables in the training set from 1 to 207 according to their discriminatory contribution; 3) we take the first ranked variable and implement the Linear Discriminant Analysis ( $L D A)$ on the test set to determine the percent of cases that are correctly classified in their historic origin group; 4) we do the same for the first and the second variable and so forth up the first 100 variables, every time recording the percent of correct classification. We repeat steps 1 to 4 for 100 iterations. The result is a final ranking of the variables based on their average ranks over the 100 iterations. We then plot the percentage of cases that are correctly classified according to the historical origin groups they were attributed to by literature in the first place, as we add the variables along their ranking from the most to the least discriminatory (fig.4).

We first notice that the curve drops considerably when variables between the 2530 positions in ranking are introduced. This "valley" behaviour flags out that cases whose urban form sits, for certain particular aspects captured by certain variables, to "the edge" of the typical range of one historical period, gets misclassified when such variables are introduced; this is further discussed in supplementary materials (SR). Second, we observe that just the first top nine variables in the ranking (tab. 4) allow for over a $90 \%$ average correct classification. For ease of reading, we offer a visual illustration of such nine topranked variables in fig. 5. Interestingly, the nine top-ranked variables remain substantially stable over all the 100 iterations, each having different test/training set splits, which grants general validity over space and time to the morphometric analysis proposed. Third (fig. 4: inset), even considering only the top nine variables in ranking, the correct classification rate between pre and post-WWII cases remains a full 100\%.

Figure 4. Cost Benefit Analysis (CBA) of the 100 higher ranked variables. Inset: Principal Component Analysis (PCA) of the forty-five $S A s$ along $P C 1$ and $P C 2$ (nine topranked $C B A$ variables).

Table 4. $C B A$ : the nine top-ranked variables.

Figure 5. Diagrammatic illustration of the nine most discriminatory variables identified by the $C B A$. 
Fourth, the nine top-ranked variables actually describe only six characters of just two components of urban form: Buildings and Regular plots. What these results suggest is that, within the limits of this research, it is possible to capture the morphological identity of forty five $S A s$ by looking at as few as three key spatial patterns: a) block perimeterness: the extent to which buildings define the street edge along the block's perimeter; b) building coverage: the extent to which a certain built volume is achieved by extending the footprint coverage on the land rather than the height of the buildings; c) regular plot coverage: the extent to which blocks are made of plots directly facing the streets rather than carved into the inner space of the block. This finding, which is indeed scientifically elegant — or better "parsimonious", in that it seems to "sum up a complex body of data in a relatively simple generalization (a pattern) [and therefore] to explain much with little" (Simon, 2001: 33) —suggests that under the seemingly endless diversity of the visible appearance of urban areas there may exist a set of very few descriptors that, alone, express almost completely their historical "identity", i.e. their belonging to a group of cases that are similar and historically characterised. We may call this set of fundamental descriptors the structure of urban form, a notion that echoes profoundly in an evolutionary interpretation of change. We would leave this generalization as hypothesis for further research, to be conducted over a much wider set of world SAS.

\subsection{Similarity Structure and Post-WWII "Bifurcation"}

We implement a Hierarchical Clustering Analysis ( $H C A$ ) over the whole set of forty-five SAs. HCAs are methods of expressing the relationship between OTUS and are common in Systematics studies (Gordon, 1996; Legendre and Legendre, 2012), as detailed in supplementary materials (SR). A typical output of HCAs is the "dendrogram" visualization, i.e. a tree-like diagram that represents the similarity of entities among a group; entities are connected by lines of similarity: the height of the point where two lines join up is proportional to the grade of similarity that they exhibit with each other, where the greater the height the less similar they are. Our dendrogram (fig. 6), where the height is expressed along the $x$ axis, reveals the similarity of $S A s$ considering only the nine top-ranked variables in the CBA. Utilizing Ward's method (Ward Jr, 1963) and considering the Euclidean distance between cases as a measure of [dis] similarity, the goodness of the fit of the clustering to the data can be measured with a Silhouette Coefficient (Kaufman and Rousseeuw, 2005): in our case a Silhouette Coefficient of 0.49 demonstrates the reliability of the dendrogram, as detailed in supplementary materials (S5).

Figure 6. Dendrogram representing the similarity structure of the forty-five $S A s$, according only to the nine most discriminatory variables.

Looking at our dendrogram, we firstly observe that the clustering of cases among the four historic origin groups is nearly perfect, satisfying once more the conditions posed by the validation theory. Moreover, the dendrogram highlights a remarkable split between pre and post-WWII cases. Again, while phenotypic similarity is not always congruent with phylogenetic relationships, it is nevertheless often an indication of them. Methods of 
estimating phylogenetic relationships amongst cases, which is the subject of cladistics, implement similar procedures as phenotypic studies but incorporate the additional variable of time in the calculation of similarity. Therefore, while it would be interesting to investigate more thoroughly the phylogenetic relationships between cases over time, it is acceptable to use the degree of phenotypic similarity as an estimation of phylogenetic similarity. In our case, the magnitude of the gap coupled with its neatness gives us a first indication that something occurred to cities after WWII that changed their profound structure and holds evolutionary relevance: with the emergence of a "new species" of cities we may in fact be witnessing the first "bifurcation" in urban evolution.

\section{Conclusions: the organic analogy revisited.}

In section 1 we stated that city dreamers, reformers, planners and designers have repetitively utilized the organic analogy to propose how cities ought to be; however we argued that they have consistently followed a developmental rather than evolutionary form of the analogy. We justified this assertion from a disciplinary standpoint, but we highlighted that such approach deeply informed the crisis of both cities and city planning after WWII. We then presented an alternative form of the analogy, truly evolutionary, by introducing and testing urban morphometrics. We showed that cities have always evolved in variations of the same structure up to WWII when a new "species" emerged - the modern city_-generating the first bifurcation of urban history. Finally, the planning ideology — we stated - was crucially important in such historical occurrence. At first sight, such findings seem contradictory: if planners continued consistently in their developmental analogy, and they were influential in shaping urban form on the ground, how can we observe the bifurcation?

The science of biologic evolution increasingly seems to offer a fertile ground for the interpretation of phenomena that go beyond the boundaries of life (Pagel, 2009b), including for example cultural phenomena (Pagel, 2009a). We view cities as evolved cultural products whose shapes and forms represent the outcomes of tens of thousands of years of cultural selection for structures that serve basic human needs. To the extent that these needs are universal to our species, we expect to see similarities in form and function across space and time. On the other hand, a hallmark of human evolution is cumulative cultural adaptation (Pagel, 2012a), characterized by the successive accumulation of technologies and social complexity. Assuming that human needs have themselves changed with these cumulative social and technological changes, we shall then see new forms and functions emerging over time and then facing the challenge of selective pressure. Our findings suggest that in a proper evolutionary analogy the $S A$ is a plausible $O T U$ for urban form classification; consequently the $S A$ is the urban form analogous of living organism, which means that physical cities are the analogous of populations of $S A s$. Moreover, if a new species of $S A s$ emerged after WWII, contemporary cities are the analogous of eco-systems of populations belonging to (at least) two different species: pre and post-WWII. As a consequence we shall conceive change in urban form as that of an ecosystem along an evolutionary trajectory. As the process of change in biology is entirely different at the individual level (ontogeny) as opposed to the population level 
(phylogeny), equally we should not confuse the two when studying cities (Porta et al., 2016).

In a phylogenetic perspective, urban forms change when adaptive variations of their codes get established over time under the selective pressure of the external environment, where with "environment" we mean the social, economic, cultural and properly environmental framework of urban change. The generative mechanism of such variations revolves essentially around errors - or innovations - in the replication of cultural codes, within and across scales; this essential mechanism appears to be one of "visual theft" (Pagel, 2012b), or "imitation" of pieces of cultural information, i.e. "memes" (Dawkins, 2006, c.1976). Because in the case of urban form such memes have a spatial content, we shall call them spemes: spemes are stored in codes of urban form such as those captured by our 207 variables. When innovations occur, mutated spemes get established only if suitable conditions characterize the environment around them, or are otherwise quickly abandoned. For example, the idea of the complete separation of different traffic vessels according to different transportation modes emerged well before $20^{\text {th }}$ century's modernists/post-modernists' urban theory (Shelton, 2011; Buchanan, 1964; Sadler, 2005) — it dates back to Filarete's Sforzinda and Leonardo da Vinci's Milan in the $15^{\text {th }}$ century. However, the idea could not get established on the ground before the automobile became a matter of mass use for the expanding middle class of the postWWII period: it is then that technological (the automobile) and socio/cultural (the rise of the middle class) "environmental" innovations radically modified the selective pressure on a sequence of new spemes, actually itself the evolution of other sequences such as the "neighbourhood unit" (Perry, 1929). These environmental changes, among many others-for example the leap in scale of housing developing agencies and later the emergence of information and communication technology, made the street separation model acceptable and even convenient to a sufficient extent to be tested, extensively reproduced (by imitation) and ultimately established. In fact, Earth scientists are proposing that the cumulative effect of all innovations occurred in the past seven decades across various aspects of society, culture, production and economy is of enough magnitude to have ushered humanity into a new geologic epoch, the "Anthropocene" (Steffen et al., 2007; Ellis et al., 2013), where human activities for the first time in history exert a tangible impact on Earth's fundamental natural forces, global warming being one such manifestations. While the origin of the Anthropocene has to be drawn back to the beginning of the industrial age, its impact started skyrocketing only after WWII configuring what is called the "Great Acceleration" (Steffen et al., 2015). The Great Acceleration theory seems just the right explanation, at just the right scale, of a profound change in the environment around urban evolution, one that justifies the occurrence of the bifurcation revealed in this paper.

In this light, the reason why cities changed so abruptly their spatial structure after WWII is not because urban planners and designers changed their attitude, but exactly because they did not, while everything around them was changing at exceptional speed and unprecedented scale. The steady attitude of urban planners and designers continued to produce spemes which, previously practicable only in few exceptional cases, found in the roaring times of post-war global urbanization an ideal environment to prosper and spread at amazing speed. The large scale, highly professionalized industrial planning and 
construction system that Christopher Alexander named "System B" (Alexander et al., 2012), which modern planning ideologies are at one time a product and a cause of, is the evolutionary outcome of a selective advantage determined by unprecedented environmental change, the cultural correspondent of a sudden glaciation, or a gigantic flood. Ultimately, the increasingly complex and specialized organization of the disciplines, professions and higher education in the post-WWII period, in itself an outcome of the evolution of the social systems (Luhmann, 1989) and another manifestation of the Great Acceleration, put "Palladio's children" at work at scales and in areas of the building process never even approached in the past (Habraken, 2005). This fact effectively supported the establishment of a mainstream "authoritarian" attitude (Hall, 2002, c.1988) to urban planning that had been previously relegated to largely minoritarian niches of ideal city dreamers and early social reformists (Choay, 1997).

In conclusion, the Anthropocene sets environmental conditions to urban evolution that make the production of cities an extremely dangerous game for life on planet Earth, the rules of which can not be approached ideologically, symbolically or mystically any longer. Historically, it is only now that urban planners and designers appear to acknowledge that Darwin actually existed and a new science of cities gives signs of emergence. A new approach to spatial urban change that makes value of adaptation and informal participation as fundamental components of how cities work is dramatically needed if the challenges of the "urbanization century" are to be met. We have never been more in need of planning and design than now, and never more than now we have been in need of innovation in the way we conceive urban planning and design. This paper is a contribution to such historical mission.

\section{References}

Adams DC, Rohlf FJ and Slice DE. (2013) A field comes of age: geometric morphometrics in the 21st century. Hystrix, the Italian Journal of Mammalogy 24(1): 7-14.

Alexander C. (1965) A city is not a tree. Architectural Forum 122(1): 58-62.

Alexander C, Neis H and Moore-Alexander M. (2012) The battle for the life and beauty of the earth : a struggle between two world-systems, New York: Oxford University Press.

Barthelemy M. (2011) Spatial Networks. Physics Reports 499(1-3): 1-101.

Batty M. (2008) The size, scale, and shape of cities. science 319(5864): 769-771.

Batty M. (2013) The New Science of Cities, Cambridge, Mass.: MIT Press.

Batty M and Longley PA. (1994) Fractal cities: a geometry of form and function, London, UK: Academic Press.

Batty M and Marshall S. (2009) The Evolution of Cities: Geddes, Abercrombie, and the New Physicalism. Town Planning Review 80(6): 551-574.

Bettencourt L, Lobo J and Youn H. (2013) The hypothesis of urban scaling: formalization, implications and challenges. arXiv preprint arXiv:1301.5919. 
Bettencourt LM, Lobo J, Helbing D, et al. (2007) Growth, innovation, scaling, and the pace of life in cities. Proceedings of the National Academy of Sciences 104(17): 7301-7306.

Boccaletti S, Latora V, Moreno Y, et al. (2006) Complex networks: Structure and dynamics. Physics Reports 424(4-5): 175-308.

Bookstein FL. (1993) A brief history of the morphometric synthesis. In: Marcus LF, Bello E and García Valdecasas A (eds) Contributions to morphometrics. Madrid: GRAFICAS MAR-CAR, S. A., 15-40.

Borgmeier T. (1957) Basic questions of systematics. Systematic Zoology 6(2): 53-69.

Brereton R. (2009) Chemometrics for pattern recognition, Chichester, UK: John Wiley \& Sons.

Buchanan C. (1964) Traffic in Towns: The specially shortened edition of the Buchanan Report: Penguin.

Caniggia G and Maffei GL. (2001, c.1979) Architectural Composition and Building Typology: Interpreting Basic Building, Firenze, IT: Alinea.

Cardillo A, Scellato S, Latora V, et al. (2006) Structural properties of planar graphs of urban street patterns. Physical Review E 73(6): 066107.

Carneiro C, Morello E, Voegtle T, et al. (2010) Digital urban morphometrics: automatic extraction and assessment of morphological properties of buildings. Transactions in GIS 14(4): 497-531.

Choay F. (1997) The Rule and the Model on the Theory of Architecture and Urbanism, Cambridge, Mass: MIT Press.

Coe NM, Kelly PF and Yeung HW-C. (2007) Economic geography: a contemporary introduction, Oxford, UK: Blackwell.

Conzen MRG. (1960) Alnwick, Northumberland: a study in town-plan analysis, London: Orge Philip and Son.

D'Arcy Thompson W. (1942, c.1917) On growth and form, New York: McMillan.

Darwin C. (1859) On the origin of species by means of natural selection: or, the preservation of favored races in the struggle for life, London: John Murray.

Dawkins R. (2006, c.1976) The selfish gene, Oxford, UK: Oxford University Press.

Dibble J, Prelorendjos A, Romice O, et al. (2016) Urban Morphometrics: Towards a Science of Urban Evolution. In: Strappa G, Amato AR and Camporeale A (eds) City as organism. New visions for urban life. Rome 22-26 september 2015 ed. Rome, IT: U+D edition, 14.

Ellis EC, Kaplan JO, Fuller DQ, et al. (2013) Used planet: A global history. Proceedings of the National Academy of Sciences 110(20): 7978-7985.

Feliciotti A, Romice O and Porta S. (2016) Design for Change: Five Proxies for Resilience in the Urban Form. Open House International.

Gordon AD. (1996) Hierarchical classification. In: Arabie P, Hubert LJ and De Soete G (eds) Clustering and classification. Singapore: World Scientific, 65-121.

Habraken N. (2005) Palladio's Children, seven essays on everyday environment and the architect. Edited by Jonathan Teicher, Editor, Oxford, UK: Taylor \& Francis.

Hair JF, Black WC, Babin BJ, et al. (2006) Multivariate data analysis, Upper Saddle River, NJ: Pearson.

Hall P. (2002, c.1988) Cities of tomorrow: an intellectual history of urban planning and design in the twentieth century, Oxford, UK: Blackwell. 
Hegewald J. (2013) Building Citizenship: The Agency of Public Buildings and Urban Planning in the Making of the Indian Citizen. In: Mitra SK (ed) Citizenship as Cultural Flow. London: Springer, 229-263.

Heywood VH. (1976) Plant taxonomy: London: Edward Arnold 63p.(Institute of Biology's Studies in Biology no. 5)-Illus.. General (KR, 197600023).

Hillier B. (1996) Cities as movement economies. Urban Design International 1(1): 4160.

Holling CS and Goldberg MA. (1971) Ecology and planning. Journal of the american Institute of Planners 37(4): 221-230.

Jacobs J. (1992, c.1961) The death and life of great American cities, New York: Random House LLC.

Jeffrey C and Heywood VH. (1977) Biological nomenclature, London: Edward Arnold.

Kaufman L and Rousseeuw PJ. (2005) Finding groups in data: an introduction to cluster analysis, Hoboken, NJ: John Wiley \& Sons.

Klingenberg CP. (2002) Morphometrics and the role of the phenotype in studies of the evolution of developmental mechanisms. Gene 287(1): 3-10.

Larkham PJ and Jones AN. (1991) A glossary of urban form, Birmingham, UK: Urban Morphology Research Group.

Legendre P and Legendre L. (2012) Numerical ecology, Amsterdam, NL: Elsevier.

Luhmann N. (1989) Ecological communication, Chicago, IL: University of Chicago Press.

Lynch K. (1984) Good city form, Cambridge, Mass.: MIT press.

MacLeod N. (2002) Phylogenetic signals in morphometric data. In: MacLeod N and Forey P (eds) Morphology, shape and phylogeny. London, UK: CRC Press.

Marshall S. (2008) Cities Design and Evolution, London, UK: Routledge.

Marshall S and Batty M. (2009) From Darwinism to planning-through Geddes and Back. Town \& Country Planning 78: 462-464.

Martin L. (1972) The Grid as a Generator. In: Martin L and March L (eds) Urban Space and Structures. Cambridge: University Press, 6-27.

Marzot N. (2002) The study of urban form in Italy. Urban Morphology 6(2): I59-74.

Mehaffy MW, Porta S, Rofè Y, et al. (2010) Urban nuclei and the geometry of streets: The 'emergent neighborhoods' model. Urban Design International 15(1): 22-46.

Moudon AV. (1986) Built for change: neighborhood architecture in San Francisco, Cambridge, Mass.: MIT Press.

Muratori S. (1960) Studi per una operante storia urbana di Venezia, Roma: Istituto Poligrafico dello Stato.

Pagel M. (2009a) Human language as a culturally transmitted replicator. Nature Reviews Genetics 10(6): 405-415.

Pagel M. (2009b) Natural selection 150 years on. Nature 457(7231): 808-811.

Pagel M. (2012a) Evolution: adapted to culture. Nature 482(7385): 297-299.

Pagel M. (2012b) Wired for culture: The natural history of human cooperation, London, UK: Penguin.

Perry C. (1929) The Neighborhood Unit. Regional New York and its environs, New York: Regional Plan Association.

Porta S, Latora V and Strano E. (2010) Networks in urban design. Six years of research in multiple centrality assessment. In: Estrada E, Fox M, Higham DJ, et al. (eds) 
Network Science: Complexity in Nature and Technology. London: Springer, 107129.

Porta S, Rofè Y and Vidoli M. (2016) The city and the grid: building beauty at large scale. In: Mehaffy M (ed) A city is not a tree, 50th anniversary edition. Sustasis Press: Sustasis Press, 163-184.

Porta S, Romice O, Maxwell JA, et al. (2014) Alterations in scale: Patterns of change in main street networks across time and space. Urban Studies 51(16): 3383-3400.

Reyment RA. (2010) Morphometrics: an historical essay. In: Elewa A (ed) Morphometrics for Nonmorphometricians. Berlin Heidelberg: Springer, 9-24.

Rohlf FJ and Marcus LF. (1993) A revolution morphometrics. Trends in Ecology \& Evolution 8(4): 129-132.

Romice O, Porta S, Feliciotti A, et al. (2017) Masterplanning for Change: Design as a Way to Create the Conditions for Time Sensitive Place-making In: AlWaer H and Illsely B (eds) Placemaking: Rethinking the Masterplanning Process. London, UK: ICE Publisher, 195-207.

Roth VL and Mercer JM. (2000) Morphometrics in development and evolution. American Zoologist 40(5): 801-810.

Sadler S. (2005) Archigram: architecture without architecture, Cambridge, Mass.: MIT Press.

Sert JL. (1942) Can our cities survive? An ABC of urban problems, their analysis, their solutions, Boston, Mass.: Harvard University Press.

Shelton T. (2011) Automobile Utopias and Traditional Urban Infrastructure: Visions of the Coming Conflict, 1925-1940. Traditional Dwellings and Settlements Review: 63-76.

Simon HA. (2001) Science seeks parsimony, not simplicity: searching for pattern in phenomena. Simplicity, inference and modelling: Keeping it sophisticatedly simple: $32-72$.

Simpson GG. (1961) Principles of animal taxonomy, New York, NY: Columbia University Press.

Sneath PH and Sokal RR. (1973) Numerical taxonomy. The principles and practice of numerical classification, San Francisco, CA: W.H.Freeman.

Steadman P. (2008) The Evolution of Designs: Biological analogy in architecture and the applied arts, Abingdon, UK: Routledge.

Steffen W, Broadgate W, Deutsch L, et al. (2015) The trajectory of the Anthropocene: The Great Acceleration. The Anthropocene Review: 1-18.

Steffen W, Crutzen PJ and McNeill JR. (2007) The Anthropocene: are humans now overwhelming the great forces of nature. AMBIO: A Journal of the Human Environment 36(8): 614-621.

Strano E, Nicosia V, Latora V, et al. (2012) Elementary processes governing the evolution of road networks. Scientific Reports 2: 1-8.

Strano E and Sood V. (2016) Rich and poor cities in Europe. An urban scaling approach to mapping the European economic transition. PloS one 11(8): e0159465.

Strano E, Viana M, da Fontoura Costa L, et al. (2013) Urban street networks, a comparative analysis of ten European cities. Environment and Planning B: Planning and Design 40(6): 1071-1086. 
U.N.HABITAT. (2013) Streets as Public Spaces and Drivers of Urban Prosperity, Nairobi: UN Habitat.

Ward Jr JH. (1963) Hierarchical grouping to optimize an objective function. Journal of the American statistical association 58(301): 236-244.

Weaver W. (1948) Science and Complexity American Scientist 36: 536-544.

Whitehand JWR. (1987) The changing face of cities: a study of development cycles and urban form, Oxford, UK: Blackwell.

Whitehand JWR, Gu K, Conzen MP, et al. (2014) The Typological Process and the Morphological Period: A Cross-Cultural Assessment. Environment and Planning B: Planning and Design 41(3): 512-533.

Williams B. (2001) The analogy of city and soul in Plato's Republic. In: Wagner E (ed) Essays on Plato's Psychology. Lanham, USA: Lexington Books, 157-167. 
Fig. 1

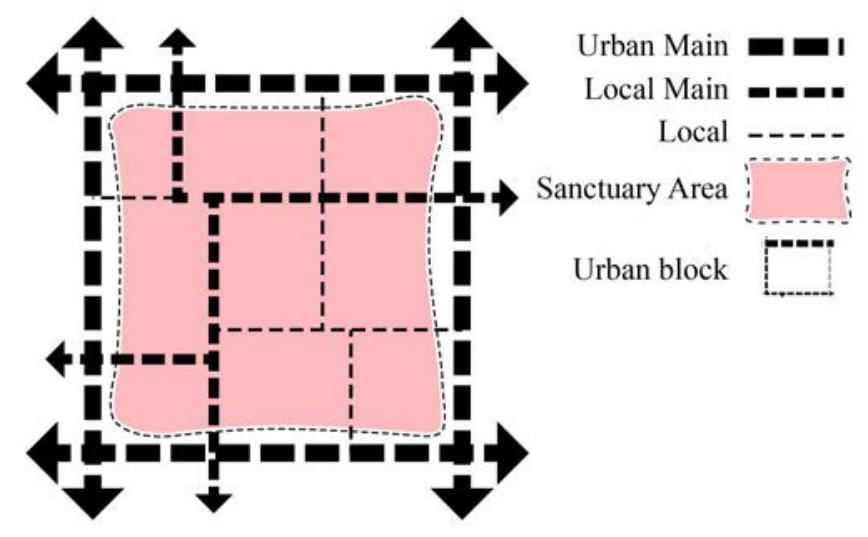


Fig. 2
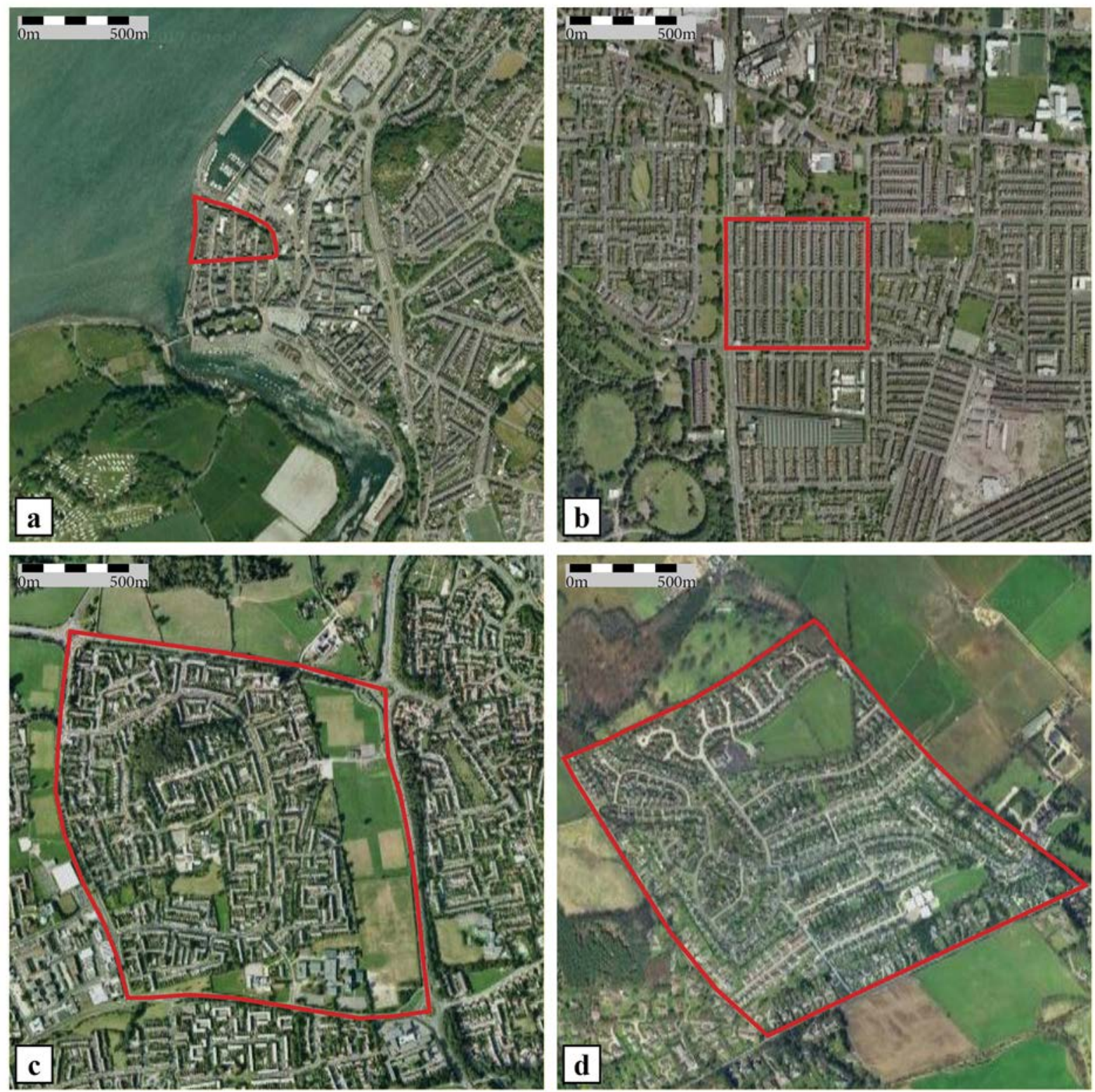
Fig. 3

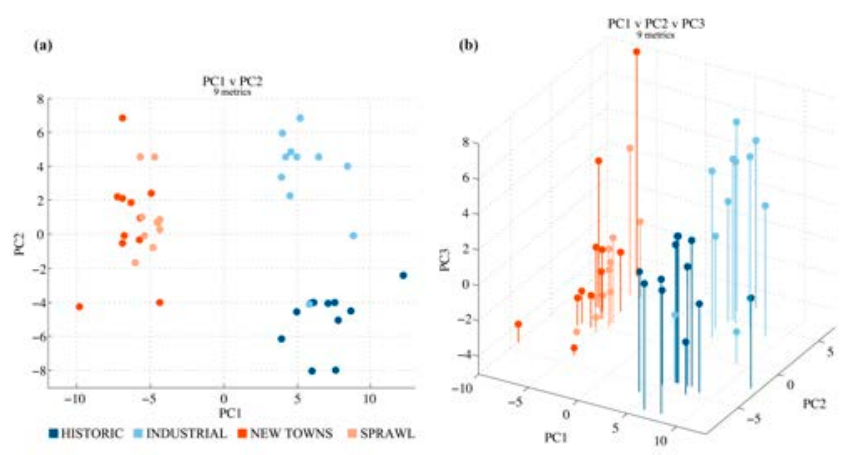


Fig. 4

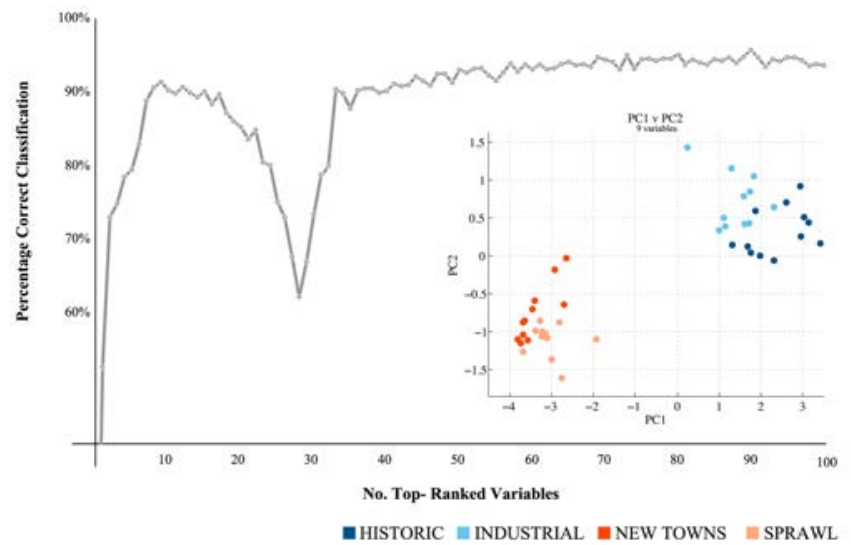


Fig. 5

\section{BLOCK BUILT FRONT RATIO}

INTERQUARTILE AVERAGE (1)

OVERALL MAXIMUM (5)

Total Extension of Built Front Block Perimeter

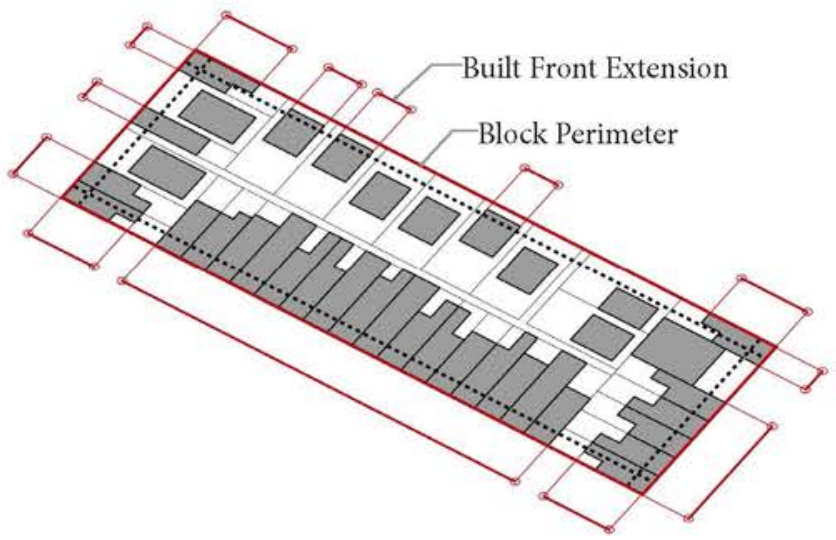

\section{LOCAL STREET BUILT FRONT RATIO}

INTERQUARTILE AVERAGE (4)

$\underline{\text { Total Extension of Built Front on Local Street }}$ Local Street Length

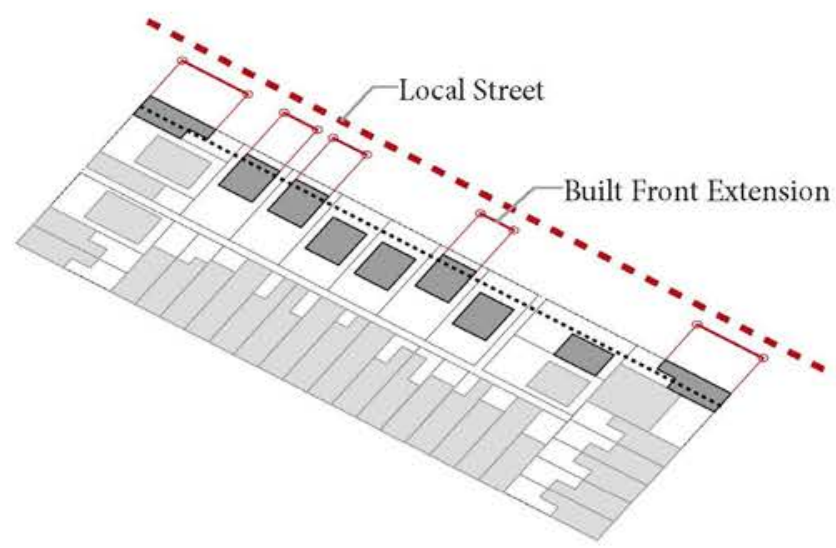

URBAN MAIN BUILT FRONT RATIO

INTERQUARTILE AVERAGE (7)

OVERALL MAXIMUM (9)

Total Extension of Built Front on Urban Main Urban Main Length

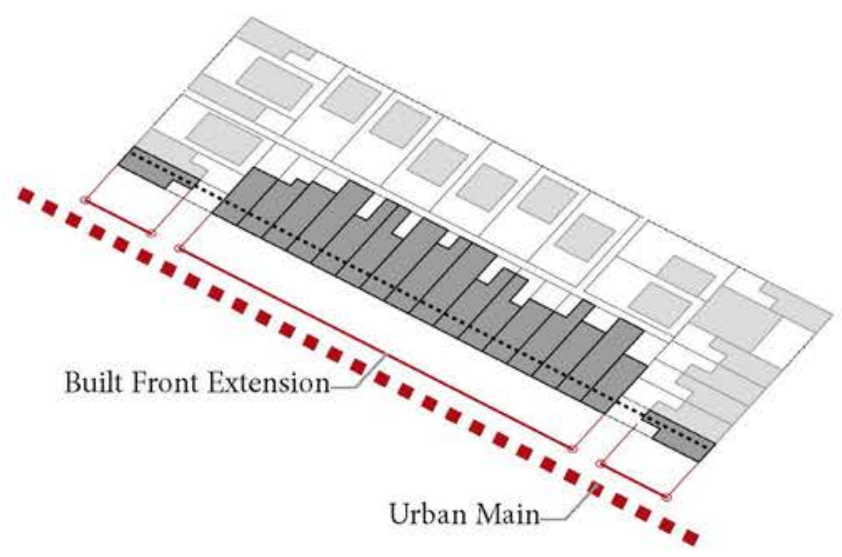

\section{BLOCK COVERED AREA RATIO}

INTERQUARTILE AVERAGE (2)

OVERALL MAXIMUM (3)

$\underline{\text { Total Building Footprint }}$ Block Area

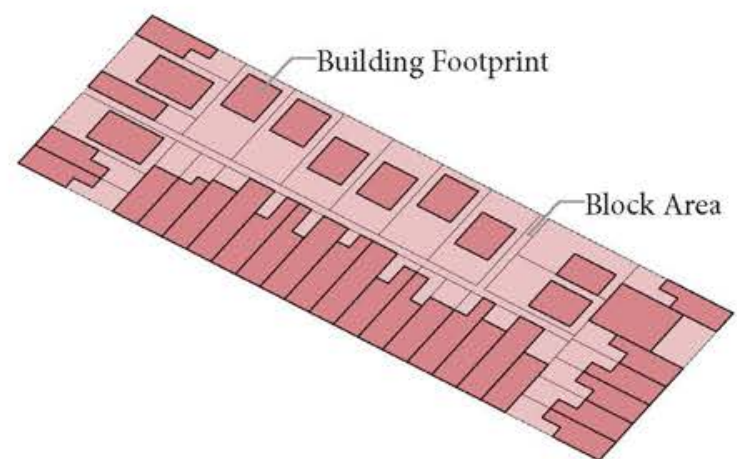

\section{REGULAR PLOT COVERED AREA RATIO} INTERQUARTILE AVERAGE (6)

$\underline{\text { Regular Plot Building Footprint }}$ Regular Plot Area

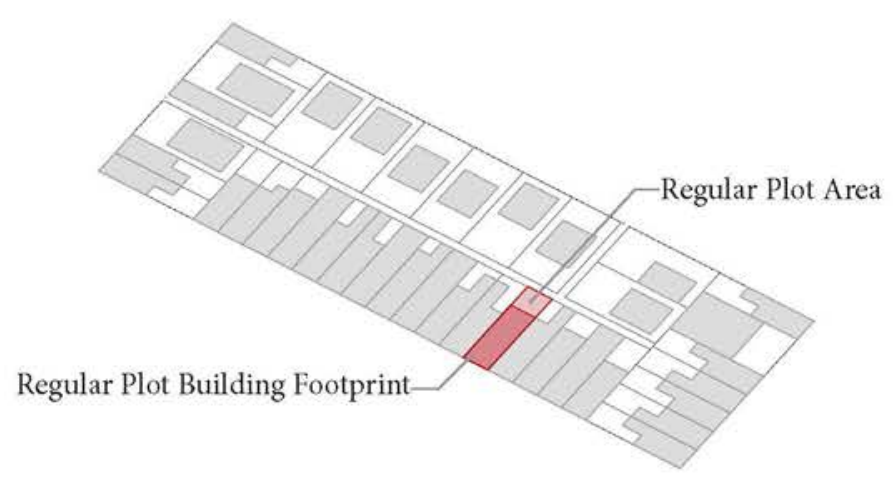

SANCTUARY AREA REGULAR PLOT RATIO (8)

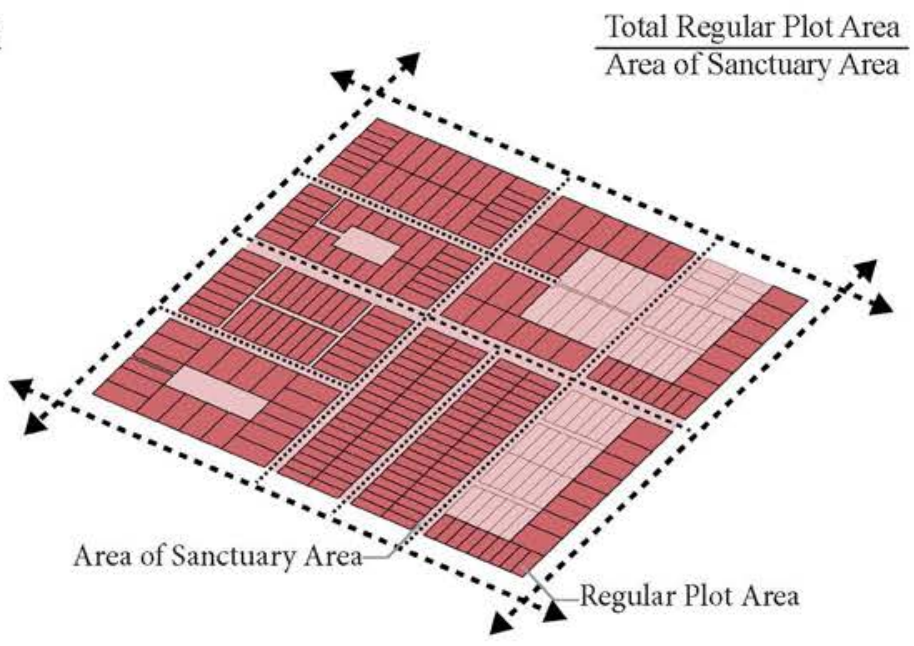


Fig. 6

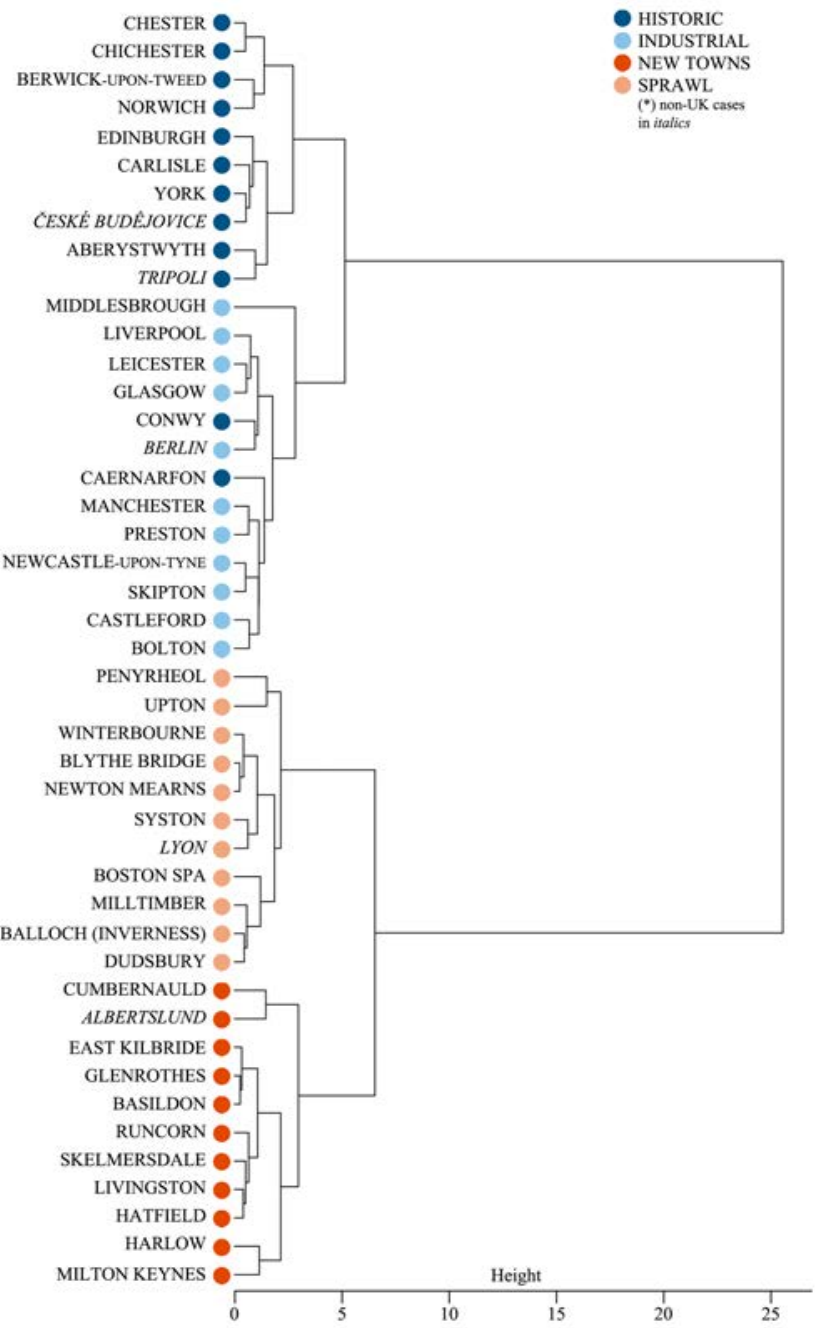


SANCTUARY A part of a city normally defined by URBAN MAINS at all its edges. Their edges may otherwise be defined

AREA by natural or artificial boundaries such as woods, agricultural or otherwise non-urbanized land, or by linear barriers such as railways, rivers, or highways.

STREET The uncovered space used for some form of surface traffic, including the associated paths and green spaces that are part of that thoroughfare. There are three types of: URBAN MAINS, LOCAL MAINS and LOCAL STREETS.

URBAN A STREET that hold a role of regional importance and, within the city, traverses three or more SANCTUARY MAIN AREAS and/or physical barriers in the urban fabric (such as railways or rivers). It is generally important in terms of movement and commerce/service globally and locally.

LOCAL A STREET that normally links together up to two SANCTUARY AREAS. It is generally important locally, to MAIN some extent, in terms of movement and commerce/service, within an individual SANCTUARY AREA, or across it especially at crossings with URBAN MAINS.

LOCAL A STREET with only an immediate importance for movement within one single SANCTUARY AREA. It holds STREET mainly a service role to residences or public services such as primary (or lower) schools or playgrounds.

BLOCK The agglomeration of contiguous REgUlar PLOTS, INTERNAL PLOTS, INTERNAL WAYS and OPEN SPACES. BLOCKS are normally defined by STREETS, however they could be defined equally in some cases by natural or artificial features such as railways or highways.

\begin{tabular}{|c|c|c|}
\hline \multirow[t]{3}{*}{ PLOT } & \multicolumn{2}{|c|}{$\begin{array}{l}\text { A *developed piece of land *partitioned from other portions of land not associated with it. that particular } \\
\text { PLOT. }\end{array}$} \\
\hline & *Developed & $\begin{array}{l}\text { Land is developed if there has been a physical human intervention to realise a specific purpose of usage. This may be } \\
\text { through the construction of a building, permanent structure or ground treatment. }\end{array}$ \\
\hline & *Partitioned & $\begin{array}{l}\text { Partitions between PLOTS in most cases exhibit some physical form of space distinction or separation, such as fences, } \\
\text { hedges, change in land coverage type and treatment. They always reflect a distinction between private and public } \\
\text { land. Within private land, they always define boundaries of land accessibility and/or control; normally - though not } \\
\text { always - this reflects individual land ownership. }\end{array}$ \\
\hline
\end{tabular}

BUILDING A permanent and covered built structure that sits within a PLOT and is dedicated to main urban uses, either residential or not residential. This definition excludes temporary or otherwise easily removable structures such as shelters or bicycle racks. BUILDINGS are always part of either a REGULAR PLOT or an INTERNAL PLOT.
REgular A Plot which both *faces a StreEt and has a primary *access from it.
PLOT
*Facing a A PLOT faces a STREET if it is oriented towards a STREET. This could be a reflection of the orientation of the STREET primary geometric edge of the PLOT, of the BUILDING's plan or its façade details.
*Access from Access to a PLOT refers to the transition from the public or semi-public space into the PLOT. Access refers a STREET physically to an entrance (door or a gate); there could be multiple accesses to a PLOT. The primary access is the one most prominent and/or most directly corresponding to the main entrance to the BUILDING.

INTERNAL A PLOT that either: a) does not *face but has a primary *access from a STREET; $b$ ) *faces but does not PLOT have a primary *access from a STREET; c) neither *faces nor has a primary *access from a STREET.

INTERNAL A space * developed within a BLOCK to serve as an internal thoroughfare, which does not hold the WAY geometric properties to be ever meaningfully turned into either a PLOT or a NATURAL AREA.

OPEN SPACE A non * developed open area that: a) does not exhibit geometrical properties to be ever meaningfully turned into either a Plot or a NATURAL AREA ("Space Left Over After Planning"); b) exhibits such properties ("Transitional Open Space").

NATURAL A space predominantly occupied by natural features such as rivers and their banks, forests or mountains.

AREA This definition does not exclude trails or sparse shelters, but does exclude areas extensively and purposefully equipped for human use such as urban parks. 


\begin{tabular}{|c|c|c|c|c|c|c|c|c|c|}
\hline N. & $\begin{array}{l}\text { Origin } \\
\text { Group } \\
\end{array}$ & $\begin{array}{c}\text { Sanctuary } \\
\text { Area }\end{array}$ & Country & Coordinates & N. & $\begin{array}{l}\text { Origin } \\
\text { Group } \\
\end{array}$ & $\begin{array}{c}\text { Sanctuary } \\
\text { Area } \\
\end{array}$ & Country & Coordinates \\
\hline 1 & HI & Aberystwyth & Wales, UK & $52^{\circ} 24^{\prime} 55.9^{\circ} \mathrm{N} 4^{\circ} 05^{\circ} 05.9^{\circ} \mathrm{W}$ & 24 & NT & Albertshind & Denmark & $55^{\circ} 39^{\prime} 19.5^{\circ} \mathrm{N} \mathrm{12} 20^{\circ} 33.7^{\prime} \mathrm{E}$ \\
\hline 2 & $\mathrm{HI}$ & Berwick-up.-Tweed & England, UK & $55^{\circ} 46^{\circ} 07.5^{\circ} \mathrm{N} 2^{\circ} 00^{\prime} 16.3^{\prime \prime} \mathrm{W}$ & 25 & NT & Basildon & England, UK & $51^{\circ} 34^{\prime} 16.1^{\prime \prime} \mathrm{N} 0^{\circ} 28^{\prime} 45.4^{\prime \prime} \mathrm{E}$ \\
\hline 3 & $\mathrm{HI}$ & Caernarfon & Wales, UK & $53^{\circ} 08^{\circ} 28.4^{\circ} \mathrm{N} 4^{\circ} 16^{\circ} 36.0^{\circ} \mathrm{W}$ & 26 & NT & Cumbernauld & Scotland, UK & $55^{\circ} 56^{\circ} 40.0^{\circ} \mathrm{N} 3^{\circ} 58^{\circ} 59.3^{\prime \prime} \mathrm{W}$ \\
\hline 4 & $\mathrm{HI}$ & Carlisle & England, UK & $54^{\circ} 53^{\prime} 45.2^{\prime \prime} \mathrm{N} 2^{\circ} 56^{\prime} 15.5^{\prime \prime} \mathrm{W}$ & 27 & NT & East Kilbride & Scotland, UK & $55^{\circ} 45^{\prime} 37.3^{\prime} \mathrm{N} 4^{\circ} 11 \cdot 55.9^{\prime \prime W}$ \\
\hline 5 & $\mathrm{HI}$ & České Budèjovice & Czech Republic & $48^{\circ} 58^{\prime} 34.2^{\prime \prime N} 14^{\circ} 28^{\prime} 31.6^{\prime \prime} \mathrm{E}$ & 28 & NT & Glenrothes & Scotland, UK & $56^{\circ} 11^{\prime} 33.3^{\circ} \mathrm{N} 3^{\circ} 11^{\prime} 13.9^{\circ \mathrm{W}}$ \\
\hline 6 & $\mathrm{HI}$ & Chester & England, UK & $53^{\circ} 11^{\prime} 20.8^{\prime \prime} \mathrm{N} 2^{\circ} 53^{\prime} 34.7^{\prime \prime} \mathrm{W}$ & 29 & NT & Harlow & England, UK & $51^{\circ} 45^{\prime} 38.3^{\prime \prime} 0^{\circ} 07^{\prime} 12.3^{\prime \prime E}$ \\
\hline 7 & $\mathrm{HI}$ & Chichester & England, UK & $50^{\circ} 50^{\prime} 06.0^{\prime \prime} \mathrm{N} 0^{\circ} 46^{\prime} 37.1^{\prime \prime} \mathrm{W}$ & 30 & NT & Hatfield & England, UK & $51^{\circ} 45^{\prime} 30.3^{\prime} \mathrm{N} 0^{\circ} 13^{\prime} 50.9^{\prime \prime} \mathrm{W}$ \\
\hline 8 & $\mathrm{HI}$ & Conwy & Wales, UK & $53^{\circ} 16^{\circ} 53.7^{\prime} \mathrm{N} 3^{\circ} 49^{\prime} 48.7 \mathrm{WW}$ & 31 & NT & Livingston & Scotland, UK & $55^{\circ} 53^{\circ} 58.6^{\circ} \mathrm{N} 3^{\circ} 31^{\circ} 21.3^{\prime \prime} \mathrm{W}$ \\
\hline 9 & $\mathrm{HI}$ & Edinburgh & Scotland, UK & $55^{\circ} 56^{\prime} 56.8^{\prime \prime} \mathrm{N} 3^{\circ} 11^{\prime} 22.4^{\prime \prime} \mathrm{W}$ & 32 & NT & Milton Keynes & England, UK & $52^{\circ} 02^{\circ} 12.1^{\prime \prime} \mathrm{N} 0^{\circ} 44^{\circ} 43.0^{\prime \prime} \mathrm{W}$ \\
\hline 10 & $\mathrm{HI}$ & Norwich & England, UK & $52^{\circ} 37^{\circ} 48.6^{\circ} \mathrm{N} 1^{\circ} 17^{\circ} 26.2^{\prime \prime} \mathrm{E}$ & 33 & NT & Runcorn & England, UK & $53^{\circ} 20^{\circ} 00.7^{\prime \prime N ~} 2^{\circ} 42^{\prime} 30.1^{\prime \prime W}$ \\
\hline 11 & $H I$ & Tripoli & Libya & $32^{\circ} 53^{\prime} 46.5^{\prime \prime} \mathrm{N} 13^{\circ} 10^{\prime} 36.2^{\prime \prime} \mathrm{E}$ & 34 & NT & Skelmersdale & England, UK & $53^{\circ} 32^{\prime} 23.4^{\prime} \mathrm{N} 2^{\circ} 45^{\prime} 39.1^{\prime \prime} \mathrm{W}$ \\
\hline 12 & $\mathrm{HI}$ & York & England, UK & $53^{\circ} 57^{\circ} 36.7^{7} \mathrm{~N} 1^{\circ} 04^{\circ} 54.7^{\circ} \mathrm{W}$ & 35 & SP & Balloch (Inverness) & Scotland, UK & $57^{\circ} 29^{\circ} 46.9^{\circ} \mathrm{N} 4^{\circ} 06^{\prime} 49.0^{\circ} \mathrm{W}$ \\
\hline 13 & $I N$ & Berlin & Germany & $52^{\circ} 32^{\circ} 34.4^{\prime \prime} \mathrm{N} 13^{\circ} 25^{\circ} 13.2^{\prime \prime} \mathrm{E}$ & 36 & SP & Blythe Bridge & England, UK & $52^{\circ} 57^{\circ} 57.1^{\prime} \mathrm{N} 2^{\circ} 05^{\prime} 57.9^{\prime \prime \mathrm{W}}$ \\
\hline 14 & IN & Bolton & England, UK & $53^{\circ} 35^{\prime} 34.3^{\prime \prime} \mathrm{N} 2^{\circ} 26^{\prime} 41.2^{\prime \prime} \mathrm{W}$ & 37 & SP & Boston Spa & England, UK & $53^{\circ} 54^{\circ} 16.0^{\circ} \mathrm{N} 1^{\circ} 21^{\circ} 21.11^{\prime \prime W}$ \\
\hline 15 & IN & Castleford & England, UK & $53^{\circ} 43^{\prime} 22.8^{\prime \prime} \mathrm{N}^{\circ} 21^{\prime} 00.4^{\prime \prime} \mathrm{W}$ & 38 & SP & Dudsbury & England, UK & $50^{\circ} 47^{\circ} 46.3^{\prime \prime} \mathrm{N} 1^{\circ} 53^{\prime} 24.1^{\prime \prime} \mathrm{W}$ \\
\hline 16 & IN & Glasgow & Scotland, UK & $55^{\circ} 50^{\circ} 12.0^{\circ} \mathrm{N} 4^{\circ} 15^{\prime} 38.6^{\circ} \mathrm{W}$ & 39 & $S P$ & Lyon & France & $45^{\circ} 49^{\circ} 09.7^{\circ} \mathrm{N} 4^{\circ} 45^{\circ} 16.0^{\circ \mathrm{E}}$ \\
\hline 17 & IN & Leicester & England, UK & $52^{\circ} 37^{\prime} 59.2^{\prime \prime} \mathrm{N} 1^{\circ} 06^{\prime} 43.7 \mathrm{WW}$ & 40 & SP & Milltimber & Scotland, UK & $57^{\circ} 06^{\prime} 29.8^{\prime \prime} \mathrm{N} 2^{\circ} 14^{\prime} 01.8^{\prime \prime} \mathrm{W}$ \\
\hline 18 & IN & Liverpool & England, UK & $53^{\circ} 23^{\prime} 33.3^{\prime \prime} \mathrm{N} 2^{\circ} 55^{\circ} 44.9^{\circ \mathrm{WW}}$ & 41 & SP & Newton Mearns & Scotland, UK & $55^{\circ} 46^{\circ} 44.2^{\prime} \mathrm{N} 4^{\circ} 20^{\circ} 47.7^{\prime \prime W}$ \\
\hline 19 & IN & Manchster & England, UK & $53^{\circ} 27^{\prime} 17^{\circ} \mathrm{N} 2^{\circ} 14^{\prime} 33.1^{\prime \prime} \mathrm{W}$ & 42 & SP & Penyrheol & Wales, UK & $51^{\circ} 39^{\prime} 55.9^{\prime \prime} \mathrm{N} 4^{\circ} 02^{\circ} 51.4^{\prime \prime} \mathrm{W}$ \\
\hline 20 & IN & Middlesbrough & England, UK & $54^{\circ} 34^{\circ} 02.9^{\prime \prime} \mathrm{N} 1^{\circ} 14^{\prime} 56.4^{\prime \prime} \mathrm{W}$ & 43 & SP & Syston & England, UK & $52^{\circ} 41^{\prime} 52.6^{\prime} \mathrm{N} 1^{\circ} 05 \cdot 25.8^{\prime \prime W}$ \\
\hline 21 & IN & Newcastle-up.-Tyne & England, UK & $54^{\circ} 58^{\prime} 38.8^{\prime \prime} \mathrm{N}^{\circ} 38^{\prime} 19.9^{\prime \prime} \mathrm{W}$ & 44 & SP & Upton & England, UK & $53^{\circ} 23^{\prime} 21.4^{\prime} \mathrm{N} 3^{\circ} 05^{\prime} 50.7^{\prime \prime} \mathrm{W}$ \\
\hline 22 & IN & Preston & England, UK & $53^{\circ} 46^{\prime} 20.2^{\prime \prime} \mathrm{N} 2^{\circ} 42^{\prime} 41.5^{\prime \prime} \mathrm{W}$ & 45 & SP & Winterbourne & England, UK & $51^{\circ} 31^{\prime} 11.5^{\circ} \mathrm{N} 2^{\circ} 30^{\circ} 15.9^{\prime \prime W}$ \\
\hline 23 & IN & Skipton & England, UK & $53^{\circ} 57^{\circ} 28.4^{\circ} \mathrm{N} 2^{\circ} 00^{\circ} 55.5^{\circ} \mathrm{WW}$ & & & & & \\
\hline
\end{tabular}




\section{CBA

1 BLOCK BUILT FRONT RATIO

2 BLOCK COVERED AREA RATIO

3 BLOCK COVERED AREA RATIO

4 LOCAL STREET BUILT FRONT RATIO

5 BLOCK BUILT FRONT RATIO

6 REGULAR Plot COVERED AREA Ratio

7 URBAN MAIN BUILT FRONT RATIO

8 SANCTUARY AREA REGULAR PLOT RATIO

9 URBAN MAIN BUILT FRONT RATIO
Interquartile Average

Interquartile Average

Overall Maximum

Interquartile Average

Overall Maximum

Interquartile Average Interquartile Average

Ratio

Overall Maximum 